\title{
EUROPE AND MANKIND.
}

\author{
HUSSERL'S BIASED REFLECTIONS ON THE ORIGIN OF PHILOSOPHY \\ AND NOT EUROPEANIZED CIVILIZATIONS
}

\author{
EUROPA Y LA HUMANIDAD. \\ Reflexiones prejuiciosas de Husserl sobre el ORIGen de LA \\ FILOSOFÍA Y DE LAS CIVILIZACIONES NO EUROPEIZADAS
}

\author{
Elmar Holenstein \\ Eidgenössische Technische Hochschule Zürich \\ elholenstein@gess.ethz.ch
}

\begin{abstract}
Nowhere does the theory-laden character of Husserl's phenomenological intuitions become as apparent as in his reflections on cultural philosophy. It is his theory that the qualification of one's own tradition as one of many manifestations of something valid in itself and binding for all is a unique achievement of GreekEuropean philosophy. However, that conviction can be found equally in South Asian (Indian) "doctrines of Oneness" as well as in East Asian (Chinese) instances of the "Golden Rule". Every person with a command of a natural language is capable of such an insight.

The most appropriate model for individual civilizations is not the sphere metaphor, which draws on a Platonic idea of organism, the model that Husserl adopted for his conception of "home" and "foreign worlds", but rather the image of tinkering introduced by Claude LéviStrauss for illiterate societies and used by François Jacob to illustrate the present biological concept of organism.

Regarding cultural universals, Husserl also relies on classical ontological reflections rather than on recent biological models. The most interesting anthropological universals from the point of view of cultural philosophy are, however, not essential, but contingent universals..
\end{abstract}

Keywords: Husserl. Cultural universals. NonEuropean philosophy. Mankind. Organism. Thinkering.

\begin{abstract}
Resumen: En ninguna parte el carácter cargado de teoría de las intuiciones fenomenológicas de Husserl se vuelve tan aparente como en sus reflexiones sobre la filosofía cultural. Según su teoría, la calificación de la propia tradición como una de las muchas manifestaciones de algo válido en sí mismo y vinculante para todos es un logro único de la filosofía greco-europea. Sin embargo, esa convicción se puede encontrar igualmente en las "doctrinas de la unidad" del sur de Asia (India), así como en las instancias del este asiático (chino) de la "regla de oro". Cada persona con un dominio de un lenguaje natural es capaz de tal idea.

El modelo más apropiado para las civilizaciones individuales no es la metáfora de la esfera, que se basa en una idea platónica del organismo -el modelo que adoptó Husserl para su concepción de "hogar" y "mundos extranjeros"- sino la imagen de retoque introducida por Claude Lévi Strauss para las sociedades analfabetas y utilizado por François Jacob para ilustrar el concepto biológico actual del organismo.

Con respecto a los universales culturales, Husserl también se basa en reflexiones ontológicas clásicas más que en modelos biológicos recientes. Sin embargo, los universales antropológicos más interesantes desde el punto de vista de la filosofía cultural no son esenciales, sino universales contingentes.
\end{abstract}

Palabras clave: Husserl. Universales culturales. Filosofía no europea. Humanidad. Organismo. Pensamiento. 
Edmund Husserl's reflections on cultural philosophy, like most of his handwritten phenomenological meditations, are impressive for the careful articulation of concrete experiences. Their originality is indebted to the fresh immediacy of his writing, rather than their substantive yield. In substance, they coincide with views of cultural philosophy that were widely held in his day. A preference for phenomenal experience obviously does not preclude adherence to biased theory. In important points of his cultural philosophy, Husserl advocates views that are not in accordance with the current state of research in cultural studies and which most probably are not adequate to address the problems facing us with the multicultural circumstances in which we live. It is time for a critical discussion ${ }^{1}$. Husserl's lasting achievements are in other fields.

\section{THE GREEK INAUGURATION OF A UNIVERSAL PHILOSOPHY}

For Husserl, what is unique about Europe, what "is recognized in us by all other human groups" consists in a novel attitude towards the environment. Husserl speaks in German of Umwelt, a term introduced by the behavioral scientist Jakob von Uexküll to characterize the world perception of animals ${ }^{2}$. According to Husserl, in European philosophy the experience of the environment is critically judged in terms of ideal truths and absolute values based on the theoretical attitude of "a few Greek eccentrics"3. A prephilosophical practical attitude leads to claims and evaluations based exclusively on additional experiences of the envi-

\footnotetext{
1 This paper is a revised version of "Europa und die Menschheit: Zu Husserls kulturphilosophischen Perspektiven", in Elmar Holenstein, Kulturphilosophische Perspektiven, Frankfurt am Main: Suhrkamp, 1998, pp. 230-253; the current English translation is by Donald Goodwin and Kate Lawn. It was presented at a phenomenological symposium at the Chinese University of Hong Kong in 2006. Lester Embree, who has done so much for "doing phenomenology" all over the globe, was a coparticipant at this cross-cultural conference.

The immediate incentive to write this essay was given a few years earlier by Klaus Held's discussion in the line of Husserl and Heidegger of the "The primordial inauguration of philosophy and science among the Greeks" in lectures delivered at the universities of Bochum and of Louvain in the Husserl memorial year 1988. Cf. his article "Husserls These von der Europäisierung der Menschheit" [Husserl's thesis of the Europeanization of mankind], in Christoph Jamme and Otto Pöggeler (eds.), Phänomenologie im Widerstreit [Phenomenology in Conflict], Frankfurt am Main: Suhrkamp, 1989, pp. 13-39, as well as my prior reading of Wole Soyinka's Nobel Lecture of 1986: "This past must address its present". http://www.nobelprize.org/nobel prizes/literature/laureates/1986/soyinka-lecture.html.

2 Umwelt could also be rendered today by "biotop". Another alternative term with more human connotations, used by Husserl in other contexts, would be "lifeworld".

${ }^{3}$ Edmund Husserl, "Die Krisis des europäischen Menschentums und die Philosophie" [The crisis of European Humanity and Philosophy], Wiener Vortrag 1935, in Husserliana VI (The Hague: Nijhoff, 1954, p. 336; English: "The Vienna Lecture", in David Carr, Trans., The Crisis of European Sciences and Transcendental Phenomenology, Evanston, IL: Northwestern University Press, 1970, p. 289.
} 
ronment. Proponents of the theoretical attitude regard these as paltry approximations to what they consider absolutely valid ideal forms of what is imperfectly given in experience.

Adopting this attitude means at once Europeanization and universalization: Europeanization inasmuch as it emerged according to Husserl "in Europe"4, and although it is only a "partial manifestation of European civilization", it is "the functioning brain, so to speak, on whose normal function the genuine, healthy European spiritual life depends"; universalization inasmuch as, "starting from this, a supranationality of a completely new sort could arise". Like every given opinion of an individual person, every cultural tradition will now be scrutinized in terms of truth per se of which it is apparently only one of infinitely many possible manifestations. According to Klaus Held, this attitude is "the fundamental mental precondition for the formation of a real world community", which, in terms of factual history, is the result of Europe's expansion to all continents.

Such a view of the history of humanity's ideas is dubious with respect to the data of comparative cultural studies, of the psychology of knowledge and of language, and with respect to the philosophical tradition in which it stands.

First, let us recall Max Weber's "affirmation", for everyone who knows it an unforgettable statement, "that in the field of thought about the 'meaning' of the world and of life there is nothing at all that has not in some form already been thought in Asia", and that in soteriological contexts it has been "elaborated in a much bolder manner" than in the Occident ${ }^{5}$. Indeed, the achievement that Husserl attributes to the Greeks can be found easily and quickly enough in Asian teachings of all-encompassing unity. For example, the following dictum has been handed down from the Daoist Zhuangzi from the fourth century BCE: "Viewed from the standpoint of the identical, the ten thousand [i.e. all] things] are one"6.

From the perspective of psychology of knowledge and of language, too, Husserl's statement about the history of ideas is not convincing. It presupposes cognitive abilities and categories that Husserl himself showed in exemplary fashion to be fundamental for everyday experience: the ability to perceive something not

\footnotetext{
${ }^{4}$ Actually so-called "European philosophy" first emerged in Anatolia, i.e. in Asia Minor, now a region of Turkey, as the work of descendants of Greek immigrants from present-day Europe.

${ }_{5}$ Max Weber, Gesammelte Aufsätze zur Religionssoziologie [Collected papers on the sociology of religion], Tübingen: Mohr, 1921, pp. 365, 375.

${ }^{6}$ Quoted in modified form from Tomonobu Imamichi, "Die freie Wanderung des Denkens nach dem Einen" [The Free Migration of Thought towards the One], in Dieter Henrich (ed.), All-Einheit [Universal Unity], Stuttgart: Klett-Cotta, 1985, p. 73.
} 
just as that as which it immediately appears, but rather on a sort of variation continuum related to an optimum of itself (the red that one perceives can always be imagined to be more or less luminous, a form to be more or less clear-cut, in the best case in a way in which it can never be encountered in reality, but only depicted as an ideal type); the intuition that one can always continue one step further on a line, infinitely; the idea of equality, the insight that various manners of appearing can be of equal value. One can wonder where a person with a command of a natural human language could have achieved such command without elementary abilities and categories of this kind.

If a claim is not tenable for objective reasons, a historical, psychological or sociological explanation can be sought for its emergence. Husserl's archaeology of philosophy has a thrust that is indeed only a slight modification of fables from the history of ideas encountered in European philosophy since the time when the systematic structure of its systems was projected onto a line of historical development, earlier stages of which still are purportedly encountered in vivo in present-day non-European civilizations. There is no need to be an expert in the history of philosophy to find older versions of Husserl's claim. It is enough to read the first African Nobel laureate's prize lecture ${ }^{7}$. Wole Soyinka quotes Hegel ${ }^{8}$ according to whom it is characteristic of the African that he has not yet "attained that realization of any substantial objective existence -as, for example, God, or Law - in which the interest of man's volition is involved and in which he realizes his own being. This distinction between himself as an individual and the universality of his essential being, the African in the uniform, undeveloped oneness of his existence, has not yet attained: so that the knowledge of absolute Being, an Other and a Higher than his individual self, is entirely wanting". For anyone who is white and also a philosopher, it is salutary to reflect on Soyinka's refined commentary on "this feat of imaginative projection", supposedly the substance of the conception of philosophy, something which according to important European philosophers was beyond his forebears: Convictions which in imperfect form are quite compatible, do not, when posited absolutely, readily remain a whole free of contradiction. Mutual tolerance (Soyinka's concern) is in grave danger if ideals

7 Soyinka, Nobel Lecture.

8 G. W. F. Hegel, Vorlesungen über die Philosophie der Geschichte [Lectures on the Philosophy of History], Vol. 12 of Werke [Works], Frankfurt am Main: Suhrkamp, 1970, p. 122. For Soyinka, the question is "in what areas we encounter differences between the histories of societies which, according to Hegel and company, never conceived of this Omnipotent Extrusion into Infinite Space, and those who did". 
that are not completely compatible with one another are elevated to absolute principles.

The Greek creation of philosophy and science probably happened no differently than other creative breakthroughs. The decisive point is not the initial idea. It is generally easy to find predecessors for that. The decisive point is what is done with it, the systematic elaboration and evaluation of this idea.

The immediate historical context of Husserl's thoughts about "the spiritual shape of Europe" was not Hegel's speculations on world history, but rather the reflections in the years after the First World War among European intellectuals about what culturally unites the nations that had so madly fought one another. It was the efforts, often well meant, to overcome the shallow idolization of national distinctiveness in terms of culture and even character, an idolization which, with the support of philosophers, was then in vogue. There is no avoiding the impression that it was sometimes an effort to secure the habitual need for a feeling of superiority on a broader and worthier, namely a supranational European basis in the face of global shifts in significance. The dialectical climax was reached in Oswald Spengler's book on the decline of the Occident. What the great majority of them lack (with the exception of studies such as Max Weber's) is the application of precisely that scientific method that is so eagerly presented as the heart of Europe's special cultural achievement. In Husserl's circle, the most committed champion of this hyper-Europeanism was initially Max Scheler". "Initially" inasmuch as even before the end of the war Scheler began to free himself of these ideas, advocating, in a manner not encountered in Husserl, "a certain balance of the specifically European and Asian" and a greater illumination of the "Asian roots" of classical antiquity and of Hellenism, which in particular has come to play a leading role in Europe's humanistic values ${ }^{10}$.

Could it be that at least the transferral of the notion of the idealized unity that remains one in the diversity of appearances to the one humanity and its various civilizations is of European origin? This, too, can be doubted. And even if it should turn out that this is the case, it would still have to be emphasized that it is only the factual emergence of this idea that can be called European (probably

${ }_{9}^{9}$ Max Scheler, Der Genius des Krieges und der Deutsche Krieg [The Spirit of War and the German War] (1915), in Vol. 4 of Gesammelte Werke [Collected works], Bern: Francke, 1982, pp. 7-250.

${ }_{10}$ Max Scheler, "Vom kulturellen Wiederaufbau Europas" [On the Cultural Reconstruction of Europe] (1918), in: Gesammelte Werke 5, Bern: Francke, 1954, p. 430. 
thanks to favorable economic and social circumstances), but not its cognitive preconditions; its factual genesis, not its categorical structure. Husserl, too, seems to have been of this view. He speaks of a "factual motivation" for the "outbreak of the theoretical attitude" that he assumes among the Greeks ${ }^{11}$. But what he adduces -cross-cultural contacts, intellectual curiosity, and the opportunity for "playful looking-about" - can hardly be called specifically European.

It is unlikely that there is a fundamental philosophical idea that is not in principle accessible to every person who has completed a normal cognitive development. At the contemporary state of research on cognitive development and linguistic universals, it is quite simply implausible that for any central idea of European philosophy it is necessary, in Karl-Otto Apel's words ${ }^{12}$, to adopt "the native language of the western mind" or to acquire cognitive categories available only in the Greek language and, mediated by its influence, in other European languages. The universal cognitive structures presupposed by natural human languages should be quite enough to be able to understand the basic philosophical concepts and assumptions.

Of course, Apel's view cannot be simply a priori dismissed. It must be tested with respect to specific linguistic structures familiar to us in our philosophical and scientific thought and at the same time lacking in some non-European languages. This has been done for unreal conditional clauses ('If I had wings, I would fly'). Alfred Bloom had hypothesized that the lack of such clauses in Chinese is one reason why the Chinese less commonly think contrafactually, and that this must be taken into consideration as an explanation for the backward state of the development of science in China ${ }^{13}$. The understanding experiments then conducted by other researchers with contrafactual stories and problems yielded evidence against Bloom's claim ${ }^{14}$. That is no surprise. It pertains to human linguistic competence not only that a person can say something in a certain way, but also that she can make the same thing understood with other linguistic or nonlinguistic means. Only if it were impossible or decidedly difficult to paraphrase in Chinese what is meant with unreal conditional clauses would an impediment to the development of science be conceivable.

\footnotetext{
${ }^{11}$ Edmund Husserl, "Vienna Lecture", p. 331f (German); p. 285 (English).

12 Karl-Otto Apel, Die Idee der Sprache in der Tradition des Humanismus von Dante bis Vico [The Idea of Language in the Humanist Tradition from Dante to Vico] (1963), Bonn: Bouvier, 1975, p. 40.

13 Alfred Bloom, The Linguistic Shaping of Thought, Hillsdale, NJ: Erlbaum, 1981.

${ }^{14}$ Cf. Lisa G. Liu, "Reasoning Counterfactually in Chinese", Cognition 21 (1985) 239-270.
} 
In such connections it seems appropriate to quote an anecdote concerning the great Chinese emperor Kangxi (1654-1722). According to Joseph Needham, the emperor is said to have insisted that for the edition of a Jesuit book titled The New Western Science of the Calendar, the word for 'Western' had to be deleted. Needham says that the emperor had indeed recognized that the science put forward in the book was new in substance, but not specifically Western ${ }^{15}$. To judge from other reportson the same emperor, he may well have thought not so much about a convergence of independently acquired and universally intelligible knowledge as of its derivability from the ancient Chinese Book of Changes ${ }^{16}$. Similarly, in Kangxi's time there were still scholars in the West who believed that transculturally convergent philosophical views were attributable to biblical influences. There is no doubt that the modern sciences have been elaborated by Europeans up to recent decades, and there is no doubt that they bear a European stamp in their linguistic structure. One could thus lean towards the following subdued claim about the worldwide Europeanization of the sciences: Outside of Europe, there may well be original approaches to and anticipations of various achievements of European modernity, but due to the historically unique upswing of the sciences in the Occident together with the worldwide economic and political hegemony of the West, the European variants have been superimposed on these approaches and anticipations, sometimes even blotting them out. To a broad global extent, only the European variants have remained in effect and decisive for further development.

Typographical printing can serve as an illustrative model for this point. It was invented in East Asia long before Gutenberg but never perfected as it was in the West. This is how it happened that the printing techniques now in worldwide use are derived from the European invention (and further developments of it) and have eclipsed home-born techniques in East Asia. Under such circumstances, however, it is never excluded that individual achievements of an eclipsed tradition will later be picked up and adopted as enrichments of the mainstream flowing from Europe. This is most readily to be expected in medicine. Therapeutics has always been a pioneer of cross-cultural influences.

15 Joseph Needham, Chinas Bedeutung für die Zukunft der westlichen Welt [China's Significance to the Future of the Western World], Bonn: Köllen, 1977, p. 25.

16 Jonathan D. Spence, Emperor of China: Self-Portrait of K'ang-hsi, New York: Knopf, 1974, p. 74. 
But considerable reservations are called for even with respect to this toneddown claim about the European character of the science and technology which have in fact been disseminated worldwide. From the very beginning and up to the early modern era, what for more than a century has triumphed over the entire planet as European science and technology is completely inexplicable without considerable influences and stimuli from other civilizations. In philosophy, influences, or at least reinforcements for convergent developments can be detected at various stages up to the middle of the nineteenth century. This influence is most obvious in the aesthetic realm. Modern arts are hardly conceivable without non-European stimuli. There is good evidence for similar claims about medieval poetry, and later, in a different manner, about some eighteenth and nineteenth century poetry. What has been repeatedly discussed in the twentieth century as "European modernity" may be a European project, but it is by no means an exclusively European product ${ }^{17}$.

This point is also overlooked outside of Europe. It is both a self-underestimation and to the disadvantage of those concerned, when modernity is rejected as something Western. The contemporary worldwide reception of the scientific achievements of the last four centuries from the west is not the reception of something specifically European: not just because in cognitive terms it is something that is universally possible for human beings, and because in its best parts it is in accord with universal human dignity, but also because something is returning to non-European civilizations that in many respects stems from them. With this return it can undergo innovations that are not to be expected in Europe. It suits such a reception that the conception of the world that the sciences are approaching - in some areas far removed from their "mechanistic" beginnings in the seventeenth century - is related to philosophical ideas that generally seem more "Eastern" than "Western". One must not be put off by the fact that the philosophical attempts to come to terms with this development are initially dilettantish and fashion-driven (currently called by the slogan "new age").

\footnotetext{
17 Looking for arguments for this view, I found a statement by Hans-Georg Gadamer in Volk und Geschichte im Denken Herders [People and History in Herder's Thought], Frankfurt am Main: Klostermann, 1942, p. 24: "The German consciousness [...] lives from the entire breadth of its origins in world history". With a view to the time, 1941, and the place, occupied Paris, of this lecture, one may overlook the wording and the concrete elaboration (which does not go farther back or beyond the "Greek polis", and excludes the "democratic chatter of the West", which, however, can be traced back to this polis).
} 
The idea of a fundamentally dynamic nature, thinking in terms of relations and continua rather than of absolute magnitudes and discrete corpuscular substances as well as the assumption that opposites complement each other and do not simply exclude each other are all called "eastern" and at the same time (scientifically) "new". It is, of course, a great difference whether venerable philosophical ideas are applied only after the fact as an aesthetically attractive superstructure to newer developments in the sciences as a sort of ideological styling, or instead have effect as background assumptions that leave their mark more or less subliminally on scientific research, as has been repeatedly claimed in Europe with respect to biblical and Greek guiding ideas. Up to now, there is only isolated evidence that is not easy to judge for such a direct effect of an "Eastern" view of the world on concrete scientific research.

There is also no guarantee that in the future innovation will remain a Europeanization, an adaptation to the West. Whether an adaptation to a foreign civilization or on the contrary an assimilation of the foreign to the own tradition occurs depends, among other things, on two very different factors: the wealth of the own history of ideas and - quite brutally- demography. Small nations can be culturally and politically absorbed by a superpower, a nation numbering a billion cannot. For China it is quite conceivable that the phase of adapting to the West will change into an assimilation of Western science, philosophy and art to Chinese traditions, which are not easily uprooted. The result would not be the continuation of the Westernization of China, but the other way round, a gradual Sinization of European achievements, at least in the Chinese sphere of influence. The ambition to such a reorientation is also not lacking in Islam and in India.

\section{THE MODEL OF CIVILIZATION: SPHERE OR TINKERING?}

Cross-cultural communication loses its hermeneutic mystery if it is recognized that the contrast between "home world" and "foreign world" is objectively not of a holistic nature as it is often subjectively experienced. Nothing is more symptomatic of this than the impossibility of drawing a clear boundary between Europe and Asia. Where do the Transcaucasian Armenians belong with their IndoEuropean language, Christianity dating back to the fourth century and even older contacts to Iran over thousands of years? The geographical delimitations that have been proposed in the course of time between the European subcontinent 
and the Asian landmass to which it belongs have never coincided with a clear linguistic and cultural boundary or even with a stable political border. Genealogical and typological delimitations generally do not coincide either. Statements such as the following by Max Weber are characteristic: "In its principles, Chinese music is closer to Hellenic than is German music"18.

"A genuinely European type of person and culture" such as Scheler imagined at the beginning of the First Word War ${ }^{19}$ exists only as an idol even if ethnic minorities are high-handedly excluded as Husserl in 1935 still excludes "the Gypsies, who constantly wander about Europe"20. The efforts to delineate "Europeanism" with specific structures of mentality, attitudes towards the surrounding world, preferred values and regularities of head gestures become grotesque when, with other peoples of the Balkan region, the affiliation of the Greeks with Europe becomes questionable 21 .

The easily entertained prejudice of the complete otherness of foreign civilizations, which tends to displace and even impede countervailing experiences, seems to be connected with a simple need for social identity. It seems to be a fundamental human need to belong to a group with which one can associate and at the same time dissociate from others. Such a group identity might be possible in a nonillusory manner with specific types of world view, lifestyles and tastes rather than with concrete civilizations. Their boundaries do not coincide with the crude boundaries generally drawn between civilizations and eras, but rather run across these, with unequal allocations of territory. The ancient Chinese sages would not have needed to warn against a "mechanistic attitude" (to use Bertrand Russell's expression) or an attitude of "world domination" (in Max Weber's catalogue) according to which for all materials, whether clay, wood, horse or human, every random form is just as beneficial as another if this were an exclusively European and modern attitude of mind. And Noam Chomsky, who sees the ultimate excesses of this attitude in fascism and behaviourism (whereas a half century earlier, Russell named, with a touch or sarcasm, the YMCA and Bolshevism),

\footnotetext{
18 Max Weber, Gesammelte Aufsätze zur Soziologie und Sozialpolitik [Collected Essays on Sociology and Social Politics], Tübingen: Mohr, 1924, p. 490.

19 Max Scheler, Der Genius der Krieges, p. 154

20 Edmund Husserl, "Vienna Lecture", p. 273.

21 Max Scheler, Der Genius des Krieges, p. 161. Scheler's reservations are based on a superficial misinterpretation of the 'yes' and 'no' gestures in southeastern Europe, which seem to be completely different from the common ones. Cf. Elmar Holenstein, Menschliches Selbstverständnis [Human ElfConception], Frankfurt am Main: Suhrkamp, 1985, pp. 143-145.
} 
could not cite romantics such as August Wilhelm von Schlegel as an antimechanistic alternative living and thinking in the midst of Europe and the modern era ${ }^{22}$.

Two civilizations $A$ and $B$ do not differ such that $A$ has a bunch of specific properties that $B$ lacks, and B another bunch of which $A$ has nothing. It can be assumed that properties that are developed in particularly pronounced form in one civilization will be detectible at least in rudimentary form in most other civilizations. What distinguishes two civilizations from each other is not so much the presence or absence of certain properties as the varying dominance of almost universally existing properties. Different properties are developed to a greater or lesser degree. Various cultural streams dominate (streams for which labels such as rationalist and empiricist, realist and idealist, legalist and pragmatic, puritan and hedonist, urban and rural, middle-class and the like are commonly used). And within one and the same civilization, the variations that are encountered among various professions, age groups, social strata, regions and eras are just as pronounced as those between civilizations. It is no accident that for Husserl the various "vocational worlds" formed the first beginnings of his conception of "particular worlds". Aside from positive law, it is not easy to find anything that occurs in only one civilization, in all its members, but not in any members of another civilization ${ }^{23}$.

A remarkable topic in the history of science is the parallels in the leading ideas of biology and of the sciences of language and culture since their emergence in the eighteenth century. By no means is it the case that biology was always the forerunner. One example is the relationship between intra- and intersocietal variation just mentioned, another is the transformation in the model of wholeness to be discussed next. Thus, at the current state of research in biol$\mathrm{ogy}^{24}$, it is assumed that there are greater variations between the individuals of one and the same human "race" than between the averages of various "races". The tallest member of a "race" of small stature may be taller than the average of a "race" of large stature. In all probability, there are no genes or chains of genes that can be detected in all members of one "race" and in no members of

22 Bertrand Russell, The Problem of China, London: Allen \& Unwin, 1922, 82f; Noam Chomsky, Cartesian Linguistics, New York: Harper \& Row, 1966). 274.

${ }^{23}$ Husserl, too, knows that cultures "flowingly interpenetrate" one another; cf. "Vienna Lecture", p.

${ }^{24}$ Stephen J. Gould, "Human equality is a contingent fact of history", The Flamingo's Smile, New York: Norton, 1985, pp. 185-198. 
another "race". There are so many and such considerable variations to be found between the individuals of one "race" that there is relatively little additional variation on making the transition to another "race". Human "races" differ from one another in a few conspicuous outward features (skin colour, hair style) that make the assumption enticing that the overall deviation will be considerable.

Husserl's approach to Johann Gottfried Herder's idea of individual civilizations as spheres ${ }^{25}$ in which all parts match each other and are oriented on a unified gravitation centre is empirically untenable and misleading as an ideal type. What is questionable is not so much the fact that this involves an assimilation of civilizations to biological organisms, with which the sphere metaphor has long been associated, but rather the classical concept of organism that leads the way here. Neither civilizations nor organisms are what they were long believed to be, harmonious wholes with a unified center in which the opposing tendencies that occur always balance each other out. It is significant that in cultural anthropology as well as in biology, tinkering has taken the place of the sphere as an alternative model $^{26}$. In something that is tinkered at, everything is connected to everything else, but it is often only loosely connected. Some things are only roughly matched with each other. Coordination is not perfect; generally, it is not hierarchically oriented on a unified center. Something that is tinkered at consists of pieces that in other contexts fulfilled other tasks that have left their mark on them, limiting them in their new application. It is not a rare occasion for something that is tinkered at to require sustained support from outside.

The ancient key passage for the sphere as a model of the organism is the myth of the circular form of primal man in Plato's Symposium ${ }^{27}$. The model was cultivated -together with Plato's reference to the form of the heavenly bodiesparticularly in the Romantic philosophy of nature 28 .

25 See Edmund Husserl, Zur Phänomenologie der Intersubjektivität: Texte aus dem Nachlass 19291935 [On the Phenomenology of Intersubjectivity: Texts from the literary remains 1929-1935], Husserliana XV, The Hague: Nijhoff, 1973, pp. 429f, 438. According to Herder, Auch eine Philosophie der Geschichte zur Bildung der Menschheit [1774] [Also a Philosophy of History towards the Formation of Humanity], Frankfurt am Main: Suhrkamp, 1967, pp. 44f: "Every nation has its centre of bliss within itself as does every sphere its centre of gravity".

${ }^{26}$ See Claude Lévi-Strauss, La pensée sauvage [The Savage Mind], Paris: Plon, 1962, pp. 26ff; and, with reference to Lévi-Strauss, François Jacob, "Evolution and Tinkering", Science 196 (1977) 1161-1166.

27 Plato, Symposium, 189d-190c.

28 Lorenz Oken, Lehrbuch der Naturphilosophie [Textbook on Natural Philosophy], Vol. II, Jena: Frommann, 1810, §§ 817, 911: "An individual, total body closed in itself and innervated and moved by itself is called an organism". "As the image of the planet, the organism must have the corresponding form. That is the sphere". Taking leave of the model of the sphere, it should not be forgotten that historians ascribe a fortuitous heuristic role to it in the early stages of cell biology (via the idea of the primal vesicle as the perfect organism). 
It is not the case, as Herder ${ }^{29}$, one of the pioneers of the Romantic movement, dreamed, that a civilization will only assimilate those points that are of its kind and which complement it, by reason of harmony rejecting everything else unfeelingly or even with contempt. Due to the diversity of human goals and the plurifunctionality of cultural structures, a harmonization in one subdomain and in one respect will lead to tensions in other subdomains and respects. If a special interest remains unsatisfied in one's own country, one will look for resources and affiliates elsewhere. Foreign civilizations accommodate the wish of individuals to be distinct from the commonplace, the madding crowd, and to display nonconformity. No more than individual civilizations are individual people homogenous structures, monotonous and lacking in inner diversity. Cultural variations help to realize the potentials and needs for development to which people are disposed and which are as broad and varied as human civilizations themselves. Just as every person has the very specific disposition for the acquisition of every natural language, so too the disposition for every human civilization, as foreign as it may be. To be aroused and developed, however, these dispositions need external stimulation.

Of course, the assumption that civilizations are unique, incommensurable wholes did not emerge unmotivated. Two overlapping reasons must be taken into consideration here, the reciprocal dependency of content and form and that between the whole and its parts.

From antiquity until well into the modern era, the dominant pattern of thought had it that people everywhere had to do with (nearly) the same things, that they have the same ideas of these things and only differ in the manner in which they give these ideas expression. With the emergence of the Romantic movement, there also emerged a gradual realization that content (meaning, function) and form (of expression) are not completely external to each other in natural systems (living beings and languages). Inasmuch as the various languages differ from one another in their phonetic and grammatical form, it was therefore reasonably concluded that they also differ from one another in their cognitive potential. Belief in cognitive universals thus became questionable.

The explosive character of newer universals research vis-à-vis classical doctrines of a grammatica universalis consists precisely in the fact that it also detects

29 J. G. Herder, Auch eine Philosophie der Geschichte, p. 45. 
general regularities on the level of expression; and according to the principle of the dependency of the content on the form, this gives cause to expect universal structures in the field of meanings. If, for example, the same regularities hold universally for the structure of semantic fields, then it is to be expected that the meaning of the individual words of such a field will be universally comparable ${ }^{30}$.

According to the hermeneutic principle of the semantic dependency between wholes and their parts, each element of a civilization can only be understood on the basis of its entire context. And this is different from situation to situation. It seems that the same structure obtains a different, specific function or interpretation depending on its changing context.

However, we must beware of untenable idealizations here. If someone were to attempt to harmonize with one another all the assumptions that guide him in his action, he would need the memory, the logical competence and (in order to calculate whether all the consequences that can be derived from these assumptions are compatible) the time of a demigod. If for the individual the unlimited validity of the hermeneutic principle lacks an empirical basis, all the more so for entire civilizations. The premature assumption that a literary work that has been handed down from antiquity forms "an original whole" results in "true madness" according to Friedrich Schleiermacher, one of the fathers of hermeneutics ${ }^{31}$. This applies all the more to large-scale phenomena such as civilizations.

The claim that despite undeniable differences in contexts there are cognitive categories and beliefs to be found almost uniformly in all civilizations is likely not only ex negativo, for lack of sufficient resources to realize convictions in harmony with one another. It also admits of positive reasons. Four assumptions can be adduced in support of it. There are good arguments for all of them.

(1) Due to the fact that neural structures are the same among humans, some stimulus constellations to which all people are exposed seem to coexist with phenomenal experiences of a very certain kind with a lawlike necessity. Just as in other realms of nature (for example in the propagation of light at a certain speed or in the occurrence of specific macrophysical properties of water in a specific microphysical situation), logical possibility (the conceivability of different constellations of properties) and lawlike natural necessity must be distinguished.

\footnotetext{
30 More on this point in Section 3.

${ }^{31}$ Friedrich Schleiermacher, Hermeneutik und Kritik [Hermeneutics and Criticism] (1838), Frankfurt am Main: Suhrkamp, 1977, p. 176.
} 
(2) Some of these phenomenal experiences are accompanied just as naturally by certain interpretations. There are not only civilization-determined, but also nature-determined intuitions. Perceptual illusions are a classical example. It is accepted that (except for limit cases) there are no theory-free experiences. It is also accepted that any set of empirical data is compatible with an unlimited number of distinct theories if enough auxiliary hypotheses are presupposed. But what is logically possible is not so readily psychologically natural. The structures required for the various theories must be equally accessible to the human mind. Though unexplained, it is an amply corroborated fact that for certain phenomenal experiences certain specific interpretations are preferred.

(3) Some of these intuitive interpretations are theory resistant. Perceptual illusions are again the best example. Although we have known for four hundred years that the earth revolves around the sun, the opposite view forces itself upon us. We may be able to overcome the opinion that persistently presents itself, but we cannot thus make the appearance that the sun moves on the horizon disappear.

(4) For lack of reflection, the self-assertiveness of intuitive convictions is stronger than the tendency towards harmonization with the other convictions that we have. Our cognitive background, which goes to influence all our explicitly developed theories, is probably full of such convictions which have never been reflected on.

The assumption of cultural universals goes hand in hand with the assumption that civilizations are not logically consistent structures in which everything and all things, in particular the background assumptions that take effect everywhere, match one another. The relative autonomy of individual cognitive structures is one presupposition for their comparability across civilizations and eras. Intracultural disunity (incoherence, plurality) makes intercultural unity (invariance, universality) possible.

\section{UNIVERSAL ANTHROPOLOGY}

Among the headwords that Husserl noted in the prologue to one of his later manuscripts is the appealing title "universal anthropology". In order to assess his contributions to this problem field, it is best to make a contrastive comparison of recent research (since about 1960) on what could be common to all languages 
and civilizations with the traditional doctrines of universals in the middle ages, the seventeenth and eighteenth centuries as well as the anthropological literature of the first half of the twentieth century. In five primary respects, the former is distinct from the latter. In one of these respects, Husserl was a pioneer, though in a way that he himself did not envisage. In a second respect, he approved of the opening without engaging in it. In the other three respects, he remained uncritically on the traditional side, which must be regarded as outdated. The differences pertain to the relationships between (1) absolute and relational universals, (2) a priori grounds and empirical explanation, (3) categories of meaning and expression, (4) abstract essential features and concrete fine structure, and (5) nature and culture.

(1) In his third Logical Investigation, Husserl did pioneering work on the laws of foundation -evidenced by his influence on Roman Jakobson-contributing to the modern assumption that it is not so much individual categories that are universal as the relationships between categories, in particular relationships of implication $^{32}$. It is for example universally valid that a language will only have a dual (a definite plural) if it also has a plural (an indefinite plural). By contrast, a plural without a dual is possible as we know from German and English. It is often the case that whole chains of such implicational constraints can be made out (trial $\rightarrow$ dual $\rightarrow$ plural $\rightarrow$ singular). Their explosive force lies in the fact that given their validity universalism and pluralism are no longer contradictory. The new universalism does not deny the diversity of languages and civilizations. (How could it?). What it disputes is the randomness of the variation. Its main interest is the universal constraints of (inter- as well as intracultural) variation.

(2) Husserl was fundamentally open for the extension of universals research from structures that can be founded a priori, ontologically or logically to structures admitting of an empirical, biological or psychological explanation. A forerunner of empirical universals research in Husserl's environment was Anton Marty ${ }^{33}$. The empirical explanation of the greater number of cultural universals is

32 See Elmar Holenstein, Roman Jakobson's Approach to Language: Phenomenological Structuralism, Bloomington, IN: Indiana University Press, 1976, pp. 2, 98-101.

33 Edmund Husserl, Logische Untersuchungen, Vol. $2\left(1913^{2}\right)$, Husserliana XIX/1, The Hague: Nijhoff, 1984, Fourth investigation, § 14; English: Logical Investigations, Trans. J. N. Findlay, London: Routledge \& Kegan Paul, 1970, Vol. 2, pp. 522ff; Anton Marty, Untersuchungen zur Grundlegung der allgemeinen Grammatik und Sprachphilosophie [Investigations on the Foundation of Universal Grammar and Philosophy of Language], Halle: Niemeyer, 1908, pp. 56ff. 
associated with the fact that many of them do not apply without exception and must be regarded merely as near universals.

The transformation that thus occurred in the history of science has not yet been adequately reflected. Kant still contrasted deduction and illustration as opposites, and not, as is today the case, logical justification and causal explanation. In human history and in everything subjective that is not of a logical nature, it was traditionally believed and is still believed by strong schools of philosophy that we are faced merely with the accidental, which can only be narrated, but not ordered in a lawlike manner. Simply trace the history of the influence of the Protagorean claim that all people have their own sense perception (as if no universal conditions could be found under which the same wine tastes sweet to one person and bitter to another, the same water seems warm to the one and cold to the other) in Western philosophy from Plato's Theaetetus ${ }^{34}$ to today. What is conspicuous is on the one hand the extension to everything subjective. Thus, for Frege $^{35}$ it holds for all subjective "ideas and intuitions" that accompany linguistic expressions beyond meaning and reference. On the other hand, in the course of time, quite clearly in Kant ${ }^{36}$, the view has become predominant that even for judgements of taste empirical generalizations are possible. Since, however, they are apparently only based on inductions, Kant uses the term 'general' for them rather than 'universal'. This superior term remained reserved for what can be logically deduced. Contemporary universals researchers in linguistics and psychology assume as a matter of course that in their sciences empirical generalizations are fundamentally susceptible to deductive-nomological explanation just as in the physical sciences.

(3) Husserl's guiding concern, "to separate the a priori sharply from the empirical"37, caused him to overlook, in conspicuous contrast to Marty, the fact that universal regularities can be found not only on the side of meaning categories, but also on the side of the expression, "with respect to the form which means of expression take on and must take on everywhere" ${ }^{\prime 38}$. Husserl remained bound to

34 Plato, Theaetetus, 161d.

35 Gottlob Frege, "Über Sinn und Bedeutung" [On Sense and Reference] (1892), in Kleine Schriften, Darmstadt: WBG, 1967, pp. 30f (original pagination).

${ }^{36}$ I. Kant, Kritik der Urteilskraft [Critique of Judgement] (1790), in Vol. V of Gesammelte Werke: Akademie Ausgabe [Collected Works: Academy Edition], Berlin: W. de Gruyter, 1913, § 7.

37 Edmund Husserl, Logical Investigations, Vol. 2, Fourth investigation $\S 14$, pp. $524 \mathrm{f}$.

38 Anton Marty, Untersuchungen zur Grundlegung der allgemeinen Grammatik und Sprachphilosophie, p. 55. 
the ancient and medieval pattern of thought according to which expression and meaning, like container and content, are completely independent of each other ${ }^{39}$.

(4) According to a view that was widespread in the humanities in the first half of the twentieth century, it is only the most basic traits that are common to people of different civilizations, but not the concrete elaboration of these basic traits, according to the pattern: all languages have functional words, but whereas we use prepositions, others use postpositions. Husserl shared this prejudice ${ }^{40}$, but in his day there was more cause to it than today. It loses plausibility when the universal traits are biologically explained. The animals of a species usually do not have only a general design in common, but also anatomical and physiological details. It is precisely such details that serve taxonomists as identifying traits.

(5) In the course of the modern era, a naturalistic reorientation of the foundation of universals occurred. The basis is to an increasing extent not logic, but rather nature. What can be considered to be universal is from now on (in Kant's words) "what nature makes of the human being", but not what the human beings make of nature, what they "make or can and should make of themselves as beings that act freely"41. What is common to all humans ${ }^{42}$ is limited to the lower layers of the foundation of mental worlds, to the physical, physiological and such psychological aspects for which Husserl, splendidly vague in this point, used the term 'animistic', speaking then of a "universal animism". According to his later reflections on cultural philosophy ${ }^{43}$, beyond this (and before the "Europeanization of humanity") it is only the ego character of the human being, its interpretation as a subject of action, that is universal: "The other person is for us a living body, an ego active in the living body, but beyond this general point a non-understood ego". In other people, the only things that are immediately familiar and accessible to empathy are "only the most proximate and universal human goals, related to the most general needs and forms (types) of satisfaction of needs occurring

${ }^{39} \mathrm{Cf}$. the evidence in Holenstein, Menschliches Selbstverständnis, pp. 128f, $196 \mathrm{f}-$ With (1) the assumption of universal ideas despite the variety of forms of expression, (2) the form of the sphere as the model of society, and (3) the application of the Protagorean principle to perceptual or subjective experience, we have encountered three guiding ideas of cultural philosophy which under Plato's influence have made their mark on European thought for centuries. In cultural philosophy, too, it becomes apparent that Western philosophy still indulges in writing footnotes to Plato.

40 Edmund Husserl, Zur Phänomenologie der Intersubjektivität, 433ff. Cf. the quotations in the next paragraph.

${ }_{41}$ I. Kant, Anthropologie in pragmatischer Hinsicht [Anthropology from a Pragmatic Point of View] (1798), in Vol. VII of Gesammelte Werke, 19172, Vorrede [Preface].

${ }_{42}$ Aside from the logical, as long as this is assumed to be autonomous.

43 Edmund Husserl, Zur Phänomenologie der Intersubjektivität, pp. $433 \mathrm{ff}$. 
everywhere among human beings, similarly related to external objects similar to each other with regard to individual type". The (linguistic, literate, aesthetic, religious, and philosophical) cultures that are built up on this basis are different from one another in a more radical manner, one that Husserl does not go into, than two trees differ from each other, the one a palm tree, the other a pine tree.

This assumption, too, does not withstand empirical examination. The most palpable universal laws concerning how human beings relate to nonperceptual matters can be found in the numeral systems of natural languages, that is, in a field of the ideal par excellence ${ }^{44}$.

An unlimited variability of "higher" mental performances would presuppose an openness and plasticity of the human mind that is hardly compatible with its finitude and the dependency of its conceptions on psychological processes. In the past, intellectualists substantiated this metaphysically with the "spontaneity of mind", behaviourists with the randomness of stimulus-response pairs depending solely on external circumstances, reward and survival advantage, free of innate constraints.

According to the then prevalent pattern of thought, nature is the lasting factor, history the changing one. Such simple classifications are, however, not possible. The colour of the eyes and of the hair are by nature innate to the human being. And nonetheless they vary. If it is assumed that there is a cognitive structure common to all human beings, then additional reasons will be accordingly needed, for example, the ability of every normal human child to acquire every natural language. It is also possible that the nature of the human being is not completely independent of his history, at least in the early stages. In particular, in connection with the development of language there are serious speculations that in the case of the human brain nature took on its form in a co-evolution of organism and civilization, through a stepwise adaptation to what "primitive" man (Rousseau's primitive, as we would have liked him) had previously made of his nature.

In uncovering cultural universals, one is today sometimes exposed to the suspicion that one adheres to a holistic ideological ideal and that one favors to-

${ }^{44}$ See Joseph H. Greenberg, Universals of Human Language, Stanford, CA: Stanford University Press, 1978 , Vol. 3, pp. 249-296. 
talitarianism in various forms. Someone who has this sort of misgiving has thoroughly missed the point. For the one part, it turns out that the assumption of transcultural invariants is only tenable if civilizations are not systems où tout se tient, where everything coheres, when not every element has an effect on the significance of every other. On the other hand, it has proved to be easier to make universal species-specific statements about all human beings (statements that apply to all human beings and only to them, but not to other living beings) than to make general population-specific statements about individual societies, nations, ethnies, civilizations, and eras.

Nonetheless, in continental European philosophy of culture, the opposite view is continually advocated, from Herder through Spengler in, one would think, an offensive continuity passing by the catastrophe of National Socialism and across ideological chasms. It is not the universalists, but rather the relativists (with their talk of "the culture or the civilization of the West", "the philosophy of China", and the like), who, in contradiction to their own intention, are the terrible simplifiers. Thus, Michel Foucault famously writes, and there are simple facts of the history of science to refute him: "In any given culture and at any given moment, there is always only one episteme that defines the conditions of possibility of all knowledge" ${ }^{\prime 45}$.

Husserl closely approached this intellectual tradition in his reflections on cultural philosophy in the thirties, although as a young philosopher he had refrained from it in his contact with Thomas Masaryk ${ }^{46}$. At the same time he became a victim of its worst excesses. When, in the last years of his life, he thought of escaping from this danger together with his work by migrating to Masaryk's country, it was already too late: Czechoslovakia, with its commitment to the cultural promotion of minorities and asylum seekers (first from the eastern, then from the western neighbor), was already as threatened as he was himself. Totalitarian claims, that is the moral of Husserl's fate, are less a global threat than a national and regional threat, one within particular states, societies, and social groups.

\footnotetext{
45 "Dans une culture et à un moment donné, il n'y a jamais qu'une épistémé, qui définit les conditions de possibilité de tout savoir" (Michel Foucault, Les mots et les choses, Paris: Gallimard, 1966, p. 179; English: The Order of Things, New York: Random House, 1970, p. 168).

${ }^{46}$ Husserl saw himself in the tradition of Thomas Masaryk, "my first educator", in his intention of "securing an ultimate scientific foundation for the spirit of a supranational humanity" with phenomenological philosophy (Karl Schuhmann, "Husserl and Masaryk", in Josef Novák (ed.), On Masaryk, Amsterdam: Rodopi, 1988, pp. 129-156).
} 
What can provide protection, as demonstrated by similar contemporary fates, is the worldwide possibility for communication and solidarity. In this respect, universalism and pluralism are not only compatible with each other, they are also conducive to each other. 